\title{
MEMORY AS AN INTERCULTURALITY BOOSTER IN MAPUTO, THROUGH THE PRESERVATION OF THE COLONIAL STATUARY
}

\author{
Vítor de Sousa
}

\begin{abstract}
Since this is a matter that is not yet resolved, where the strength of ideologies and reuses may change deeply or even reverse the ways it is evoked, the colonial past may become a problem (Vecchi, 2018a). This is the case of Portuguese colonialism which is frequently invoked to stress resentments: whether from the country that was colonised or the colonising country (Ferro, 2009). As soon as the Portuguese Revolution of 25 April 1974 took place, Mozambique promoted the elimination of colonialism symbols. This predictable attitude, aiming to show that the colonisation had ended, was later amended by the future Governments, with the colonial statues (at least, the ones that remained) being relocated to a place where they may be observed and contextualised. This action aimed to preserve the memory, which may enable the development of intercultural dynamics, softening the mentioned resentment: promoting questioning, in order to understand certain logics and, at the same time, filling gaps in the forgotten memory and in the Mozambican identity (Khan, Falconi \& Krakowska, 2016). This paper refers to the cases related to the new life of two colonial statues in Maputo - Mouzinho de Albuquerque and Salazar -, during the post-colonial period and the permanence, until today, of the first monumental trace of Estado Novo [Second Republic] (Monumento aos Mortos da Primeira Guerra Mundial [World War I monument]), showing the importance that the preservation of memory has in a country or a nation's life, even when it is associated with the former coloniser. This sort of mental decolonisation (Mbembe, 2017; Thiong'o, 1986), aims the questioning of the way the colonial past weighs on the current intercultural relations, in Mozambique, when the country establishes a relation with the former coloniser, allowing its inhabitants to look at the past as a way to build future dynamics.
\end{abstract}

\section{A MEMÓRIA COMO PROMOTORA DE INTERCULTURALIDADE EM MAPUTO, ATRAVÉS DA PRESERVAÇÃo DA ESTATUÁRIA COLONIAL}

\begin{abstract}
Resumo
Por não se tratar de um assunto encerrado, onde a força das ideologias e dos reusos poderá alterar profundamente, ou até inverter, os modos da sua evocação, o passado colonial pode revelar-se problemático (Vecchi, 2018a). É o caso do colonialismo português que, de forma recorrente é invocado para sublinhar ressentimentos: quer do país que foi colonizado, quer do país colonizador (Ferro, 2009). Moçambique, logo que eclodiu em Portugal a Revolução do 25 de Abril de 1974, promoveu o apagamento dos símbolos do colonialismo. A previsível atitude, tendente a mostrar que a colonização tinha acabado veio, depois, a ser corrigida pelos futuros Governos, com as estátuas coloniais (pelo menos as que restaram), a serem deslocalizadas, onde passaram a poder ser observadas e contextualizadas. Tratou-se de uma ação com vista à preservação da memória, que pode permitir o desenvolvimento de dinâmicas interculturais, esbatendo o referido ressentimento: promovendo a problematização para perceber determinadas lógicas e, ao mesmo tempo, preencher vazios na memória esquecida e na identidade dos moçambicanos
\end{abstract}


(Khan, Falconi \& Krakowska, 2016). Este artigo referencia os casos relativos à nova vida de duas estátuas coloniais em Maputo - a de Mouzinho de Albuquerque e a de Salazar -, em tempo pós-colonial, e à permanência, até hoje, daquele que foi o primeiro vestígio monumental do Estado Novo (o Monumento aos Mortos da Primeira Guerra Mundial), observando a importância que tem a preservação da memória na vida de um país, ou de uma nação, mesmo estando associada ao antigo colonizador. Esta espécie de descolonização mental (Mbembe, 2017; Thiong'o, 1986), passa pela problematização da forma como o passado colonial pesa nas relações interculturais nos dias de hoje em Moçambique, quando o país se relaciona com o antigo colonizador, permitindo que os seus habitantes olhem para o passado como forma de construir dinâmicas de futuro.

\section{PALAVRas-Chave}

Memória; história; colonialidade; pós-colonialidade; interculturalidade

\section{INTRODUCTION}

Statues are present in public spaces, such as cities, where major communities are settled. As public monuments, they express collective memory and its representations, and they are usually related to themes or figures connected to national identity, through those in power in those circumstances.

A statue is an immovable object (three-dimensional sculpture), which may represent a real or imaginary entity. Colonial governments built statues in the colonised territories, related to the metropolis or to their imagination. Margarida Calafate Ribeiro (2004) mentions the "empire as an imagination of centre", claiming that the creation of an image of Portugal as a centre was achieved precisely through the empire. It was the empire's traces, which represented the "excess nation, relocated far away" (Richards, 1993), especially in the relation with the "imagined communities" (Anderson, 1993), that tried to establish the connection. Even if it was a "Paper Empire", as stated by Leonor Pires Martins (2012), in which the African regions started taking shape in the Portuguese heads through the images, although showing some fragility from Lisbon.

Mozambique, namely its capital, Maputo (once Lourenço Marques), was not an exception. In a first phase, just before the country's independence, in June 1975, the colonial statues were demolished (except the World War I monument, made of stone) and many of them were damaged. In a second phase, the Mozambique Government aimed to show the previous statuary, preserving the memory and contextualising it. This is the case of the equestrian statue that honoured Mouzinho de Albuquerque, which was located in the heart of Maputo (demolished in May 1975), in the square named after this Portuguese soldier during the colonial period, who was the Royal Commissioner of Mozambique between 1896 and 1898 . This statue was transferred to the Maputo Fortress, where it could be seen by all the inhabitants and newlyweds used it as a backdrop for their wedding photos. In addition, another statue representing Salazar, which was built in the centre of the capital during the colonial period (demolished in May 1974), was placed in the National Library of Mozambique, facing the wall, as if it was being punished. In both 
cases, it is a sort of mental decolonisation (Thiong'o, 1986; Mbembe, 2017), which aims to question the way the colonial past currently weighs on Mozambique. In this sense, although the concept of interculturality may not be too consensual - being associated with the Portuguese Discoveries, in a clearly tropical Portuguese inspiration -, the truth is that, during the Portuguese period, a sort of reversed interculturality (Stoer \& Cortesão, 1999), protected by the coloniser, with emphasis on the idea of "Portugality", prevailed.

The post-colonial period does not erase the colonial time, although it does recycle it. Therefore, and as a metaphor of the past-present time, the colonial statue represents an absence/indifference, but, at the same time, duly contextualised, it can be assumed as a cornerstone of the memory of Mozambique and, by extension, of Portugal as well.

\section{COLLECTIVE MEMORY AND HISTORY}

In some countries, heritage, like patrimony, becomes a watchword, evoking a multiplicity of emotional associations. For the State, it constitutes an opportunist means to satisfy the social needs of the electorate, at the same time that it promotes the political goals of nation building. In Sabine Marschall's opinion (2009) - who wrote about the idea of heritage during the post-apartheid period in South Africa -, heritage is based on a malleable and ambiguous concept, full of paradoxes, and it can be used differently, sometimes supporting contradictory political, economic, social and cultural ideas. Since the beginning of the 1990s, that the patrimonial heritage speech arose - not only in South Africa, but also in several other countries -, as one of the main places to discuss questions of culture, identity and citizenship, suggesting what is authentic, what are the deeper roots of cultural identity and the "essence" of a sense of nationality (Shepherd \& Robins, 2008). Patrimony is hard to define, because it is comprehensive, contains tangible artefacts and structures that refer to the past, as well as intangible landscapes and aspects of culture, such as traditions, customs and oral memories. Patrimony relates to both the past and the present (Marschall, 2009).

The celebration is demonstrated, among others, through the renaming of streets, cities and public buildings; in the construction of new museums, documentation and interpretation centres; in the re-enactment of battles and historical events; in the identification and official marking of new patrimony places; as well as in the installation of memorials, monuments and public statues. As public monuments, statues express collective memory and representations, and are usually related to themes or figures connected to national identity, through those in power in those circumstances.

Maputo did not escape that trend, although the destruction of colonial traces felt following the Portuguese Revolution of 25 April, right before the independence of Mozambique, had been replaced by its preservation, in an attempt to show the Mozambican people memory traces from the Portuguese domination period.

Collective memory - a concept created by Maurice Halbwachs, in 1925, after concluding that memory is shared, transmitted and built by a group or by society -, should always be considered in its multidimensionality, since the individual memory of a person 
or related to a country are the basis for formulating an identity. At another level, there is history, which promotes the summary of the important events of a nation, which makes collective memories only a sum of details. Regarding the relation between history and memory, the author refers that "history starts only when tradition ends and the social memory is fading or breaking up. So long as a remembrance continues to exist, it is useless to set it down in writing" (Halbwachs, 1990 [1950], p. 80).

This idea is also shared by Pierre Nora, although this historian observes that memory has become an object of history, so it corresponds to history itself. He highlights that the acceleration process verified in history, resulting from the mediatised massification of society, has produced the end of memory tradition, as a consequence of the radical change of practice related to archives, which no longer have a critical view, only being used as instruments, contracting "live memory". In this sense, he mentions the crystallisation of forms of memory, considering them as "prosthetic memories", which substitute the experience lived (Nora, 1989). He advocates the idea that memory no longer exists, since it is only relived and ritualised, therefore, nowadays, society uses history to grant it memories. In this sense, in contemporary society, there is no possibility for a memory-history, as in the $19^{\text {th }}$ century. He refers that the separation between memory and history produces well-defined meanings, with memory being considered a tradition based on live and dynamic heritage, and history representing the opposite, separating and selecting the facts. Thus, the historian refers that modern societies completely eliminate memory, and the one that exists is assumed as history. And, in the event of not having memory, he mentions the possibility of accessing a reconstructed memory that gives sense to identity, such as the creation of archives, organisation of celebrations, among others, in which the sites of memory are assumed as a space where the ritual of a historymemory can be translated into a memory (Nora, 1989).

The cultural, historical and educational narratives establish memories and postmemories, being its productivity demonstrable through, for example, an analysis of memoralisation of the Colonial War in the Portuguese contemporary context (Ribeiro \& Ribeiro, 2018), and that, in this context, is also relevant to Mozambique.

According to António Sousa Ribeiro (2018), one of the most productive reflections on these themes is translated into the concept of "postmemory", proposed by Marianne Hirsch, in the 1990s, whose importance is "based on the way it allows thinking about the complex position of the subsequent generations in the scope of the memory processes" (Ribeiro, 2018, p. 15). Paradoxically, "postmemory" will be considered a memory that was not lived, but that "by its violence and the important meaning of its consequences, namely in the scope of family socialisation, stands out to the next generation with enough strength to be indelibly inscribed" (Ribeiro, 2018, p. 15). It is in this sense that postmemory "is transformed into one of the cornerstones that gives a specific performative content to the relation with a violent past" (Ribeiro, 2018, p. 15). This also enables codifying those memories in stories and narratives, preserving them and allowing new members to share a story in group.

Sheila Khan stresses the existence of a Mozambican post-colonialism, differentiated from the post-colonial dynamic of the expression in the Portuguese language, a 
fact she mentions stands out in João Paulo Borges Coelho's writing. The researcher approaches three author's works - As visitas do Dr. Valdez [The Visits of Dr. Valdez] (2004), Crónica da Rua 513.2 [Chronicle of the 513.2 Street] (2006) and Campo de Trânsito [The Camp of Transit] (2007) - looking to a "Story of the 'silent', [where] the margins, the silences, the fragilities of all of those who witnessed the cycles, the transitions, the changes of this nation being built that is Mozambique [are appointed]" (Khan, 2008, p. 134).

After a conversation with the writer and historian, Sheila Khan refers that the social and collective memory is interlocked in a process of "organisation of a national identity", although it presents another dimension, which is related to "the legitimacy of its power, as narrative holder, of a sort of meta-narrative of History", that, after all, is nothing more than "the struggle for liberation, [which] legitimates its power, and which means pulling out the entire past (...) of demonising the entire colonial past"'. Therefore, in the author's diegesis, it is assumed "as a link of contrasts, of signs that project, (...), precisely in what concerns the denunciation of a political attempt to establish a rupture (...) between the colonial and post-colonial periods" (Khan, 2008, pp. 134-135). In which it is clear "the intersection between the social memory and the elimination or oblivion, strategic or political, of that other colonial period, which is urgent not to forget, delete or conceal" (Khan, 2008 , p. 135). Furthermore, it remains in the generation that lived the Colonial War, a confrontation with its own process of cultural, identity and physical deterritorialisation. Or, as the character Sá Caetana (As visitas do Dr. Valdez, 2004) mentions: "we belong to the old world, we don't have the strength of the new one" (Coelho, 2004, p. 204).

The colonial past is present in the contemporary world in many different ways, being integrated in a material culture in several forms. In a maybe less tangible way, but not less active, it shapes society, recognising positioning (L'Estoile, 2008). According to Roberto Vecchi, the empire "explodes today in multiple subjective splinters, whose shape is not yet formed and it is subject to the risk of partial reuses or interested reviews" (2018a, p. 18). A transfer of memory between generations is taking place, "which allows a glimpse of possible survivals, of distant and fragmentary pasts, by the strength of an image caught by a glance that does not reproduce it, but recreates it" (Vecchi, 2018a, p. 18). And this is what will remain, when there are no longer live witnesses of the events.

The ideologies and social memory regarding the colonial past between the Portuguese speaking countries, without being subject to reflection and critical deconstruction, may contribute to Portuguese-centric expressions and social stereotypes, and lead to intergroup conflicts, social discrimination and exclusion of some people (Abadia, Cabecinhas, Macedo \& Cunha, 2016; Cabecinhas, 2007; Cabecinhas \& Feijó, 2010; Feijó \& Cabecinhas, 2009; M. L. Martins, 2015; Sousa, 2015, 2017). In fact, the collective memories regarding the colonial past generate tension between the so-called "Portuguese speaking nations", whose contact with hegemonic versions of the colonial past was provided by cultural, educational and historical narratives that have been frequently mobilised to strengthen national identity and justify policies.

Sheila Khan, personal interview, July 19, 2007. Interview with João Paulo Borges Coelho. Sines, Portugal. 
Cultural memory (Assmann, 2008) - or the bond between the past, present and future - constitutes a continuous process of remembrance and oblivion, in which the reconfiguration of individuals and of the group itself with the past remains, with its positioning made in terms of the emergent and established sites of memory. Hence, the cultural memory dynamic must be contextualised, taking into account the social factors on which it sails and the way power was exercised.

\section{PresentisM, POST-COLONIAL THEORY AND INTERCULTURAIITY}

Memory has transformed, from a cultural and political point of view, into a fertile ground, where a tough battle for the building of a hegemonic narrative is being fought, with one of the participating factions claiming its own truth or, at least, its memory authority. We still look at history as if it was built between good and bad people, but history is much more complicated than that. According to Diogo Ramada Curto, this is a deviation of a question that is urgent to ask and that is related to the situation of historical research. He argues that the past should be studied through the intersection of history and social sciences in general, based on sources and the development of an analytical practice that prevents a moralist one: "that allows us to think about social differences on a scale that transcends the nation, to compromise migrations and population movements" and that also enables "as better understanding of the big structures that, with the force of inertia, continue to impose themselves in the present, complicating the modernisation of societies, such as the Portuguese", preventing presentism (Curto, 2018, s. p.). It is exactly in this direction that the most recent research of the historian António Manuel Hespanha (2019) goes. In Filhos da Terra: identidades mestiças nos confins da expansão portuguesa [Portuguese children: interracial identities at the ends of the Portuguese expansion], the history of the Portuguese expansion is told not from the metropolis point of view, but from the point of view of those who left and settled in the lands of the Portuguese empire. Hespanha refers that this publication aims to gather and process together "elements for the analysis of what has been called, for some years, the Portuguese 'shadow empire', which means, that set of communities (...), mainly in Africa and Asia, [that] were considered 'Portuguese'" (Hespanha, 2019, p. 12). Therefore, he questions the existence of a "'Portuguese' identity", assuring that the problems start there, with the definition of the object of study. In fact, as the "Portuguese" communities are being considered, in their ambiguity and complexity of their constituent elements, "their identity is lost". And he explains: "they are so different from one another that, grouping them is, above all, the result of having decided to look at them together. And (...) we have concluded that is related (...) to the way we previously imagined them as "Portuguese'" (Hespanha, 2019, pp. 12-13). Drawing on Sanjay Subrahmanyam (1995), he even demonstrates doubts regarding the applicability of the expression "Portuguese Diaspora" 2

\footnotetext{
${ }^{2}$ Stuart Hall had already mentioned that "the diasporic perspective of culture can be seen as a subversion of the traditional cultural models oriented to the nation" (2013, p. 36), even more so, in a time of globalisation, the diaspora concept may be a contradiction when evoked in the name of "Portugality" (Sousa, 2013).
} 
Moisés de Lemos Martins (2018) considers that the European maritime expansion of the $15^{\text {th }}$ and $16^{\text {th }}$ centuries was a process that opened to alterity, diversity and knowledge of the other, but it failed to assimilate and destroy the entire difference, producing colonialism. What was stressed during Estado Novo, in which the inoculation of ideology together with the colonised territories was done since school, highlighting the "values" that were the basis of the regime. This made Sephen R. Stoer and Luiza Cortesão stress the "heavy legacy of 'Portugality', as a 'reserved interculturality", justified through the attempt of that regime to try to assign a "built homogeneity", through curricula, teachers, school materials, in which the education process was assumed as "one of the ways resorted to, in an attempt to awake/develop the sense of belonging to that dispersion/diversity" (Stoer \& Cortesão, 1999, p. 59). This contradicted the existing rhetoric in Estado Novo, under the development of an assimilationism policy, although controlled, ending in the 1960s, already in full assimilationism, in which the indigenousness law was even extinguished, giving Portuguese citizenship to the natives (Torgal, 2009).

Rosa Cabecinhas and Luís Cunha (2008) thus typify interculturality as a distant plurality of the exotic diversity spread through the Estado Novo propaganda. Interculturality should be seen as a process, which means that several people with different inequalities participate in it, and that it is important to understand "that the places where we live and the frontiers that separate us constitute realities that, to a large extent, are irremovable, therefore transcending any multicultural rhetoric" (Cabecinhas \& Cunha, 2008, p. 7). It is important to understand that the smaller world globalisation provide is not directly proportional to "different ways to state inequalities" (Cabecinhas \& Cunha, 2008, p. 7). However, the authors alert to the risk of "confusing dialogue with symmetry and interculturality with equality of the parties", which arises from an attempt to simplify processes, although that attitude is "more appropriate of an imperial imagination recycled in postmodern shades, than from a challenging view, and that aims, in fact, to create renewed senses and fairer ways of life" (Cabecinhas \& Cunha, 2008, p. 7). The famous dialogue with the 'other', is almost summarised in a folkloric dimension, even if the opening up to the 'other' means "reciprocal transformation", since, in this entire process, the expectation is that an asymmetry exists based on the idea that "the other should think like us, because we think better" (Cabecinhas \& Cunha, 2008, p. 9).

João Maria André (2005) proposes some principles aiming for the promotion of intercultural dialogue, that imply the knowledge of the "other" as a determining fact for the development of a practical action, based on a critical awareness that is necessary for social transformation. This intercultural logic undergoes the challenge of a universal declaration of human rights, another formulation of universality, based on pluralism and that is not imposed, in addition to the recovery of the fundamental traits of each culture, valuing its symbolic contour.

That is why the definition of "Interculturality" in Dicionário da Expansão Portuguesa (1415-1600), raises many doubts, because of the fact that it is precisely associated with the Portuguese expansion, although translated as a concept that appeared in France, in the 1970s, within the education sciences, during a period of increase in immigration (Lacerda, 
2016, p. 588). The use of this concept in the study of previous eras is justified by the need of identifying, in the past, phenomena similar to those intended with an intercultural education. For this purpose, processes that imply cultural exchanges and amalgamation and not only knowledge or interaction with a different culture are analysed: "Interculturality is related to other concepts, such as acculturation and syncretism, but it clearly distinguishes itself from multiculturality, which only entails the interaction of two stratified and hierarchical cultures" (Lacerda, 2016, p. 589). So, according to the mentioned dictionary, the culture of Portuguese expansion - as with all cultures -, "was the result of an osmosis process, which was developed by the clash, acceptance and rejection of aspects of communicating cultures" (Lacerda, 2016, p. 589). The agents of the Portuguese expansion were not aware of this process, but they almost always behaved "as bearers of a finished culture, even considering that some of its matrices, namely Christianism, were superior forms that should be spread" (Lacerda, 2016, p. 589). From this belief and from the resulting behaviours, according to Teresa Lacerda, "processes of acculturation that generated intercultural phenomena" were born (Lacerda, 2016, p. 589).

This is a tropicalist Portuguese view of the Portuguese expansion history, given that it is, at least, very questionable, associating it to an interculturality contour, when power was, at that time, unilateral, with the one-way direction being on the side of the colonising country, and those who did not obey the rules imposed, suffered the respective consequences.

It is in this sense that not considering the differences between colonial histories and colonisation processes may impose over a nation the post-colonial narrative of another nation, making that people even less visible, as stated by Ana Paula Ferreira (2007). Which means that colonialism "may be speaking on behalf of a critical, off-centre and non-hegemonic post-colonialism" (Ferreira, 2007, pp. 22-23). According to Pedro Shacht Pereira, this "represents an appropriation of a critical metalanguage, historically decontextualised, even when made with the best of intentions" and that entails "considerable theoretical risks, namely the fact of voluntarily perpetuating the colonial relation that is intended to be abolished to another level" (2017, s.p.).

As mentioned by José Neves (2016), historical knowledge depends on empirical elements from a certain past, as well as the use of new theoretical and conceptual tools that are determined in the present, given that in history no topic may be considered closed. On the other hand, Paul Ricoeur (2000) had already confirmed the inseparability between memory and oblivion, and, as Sanjay Subrahmanyam (Meireles, 2016) refers, the main job of a historian is not to remember, since the job is developed in the direction opposite to the dynamic of believing in memory, even going against it, since it has been revealed to be false. According to Tzvetan Todorov (2002), memory is a sort of selective consciousness of time, that is not opposed to oblivion. Memory is an interaction between elimination and preservation, given that the full restitution of the past is impossible, since memory always involves a selection. The historian Fernando Bouza even quotes an African proverb that synthesises what was mentioned regarding the memory modus operandi: "memory goes to the woods and brings from there the wood it wants" (Canelas, 2014). 


\section{The statues of Mouzinho de Albuquerque, World War I monument and Salazar RECYCLED}

A statue is an immovable object (three-dimensional sculpture), which may represent a real or imaginary entity. Colonial governments erected statues in the colonised territories and that materialised their imagination, in a logic of centre from the colonising metropolis, showing the symbolic relation between Portugal and its empire. Margarida Calafate Ribeiro (2004) takes the concept of "imagination of centre", from Boaventura de Sousa Santos, and renames it "an empire as an imagination of centre". She claims that the creation of an image of Portugal as a centre was achieved through the empire, concealing a "Portuguese image connected to its existential reality of periphery that 'imagines the centre"" (Ribeiro, 2004, p. 12). That ideology dates back to the period of the Portuguese expansion, given that colonialism is not a movement of one-way direction, since it 'affected' both the colonised countries and the colonising ones. Therefore, maybe this way it is possible to understand the idea of Thomas Richards (1993), who refers to the empire as an excess nation, which was relocated far away (maybe too far), conquering territories, without the respective control being an easy task. As remarked by Leonor Pires Martins regarding the Portuguese colonial empire (Um império de papel [A paper empire] 2012), the idea of nation shifted to a "huge gathering of territories, disperse and distant from each other, whose direct and effective domain would end up being more fictional than real, more illusory than factual" (Martins, 2012, p. 20).

In fact, it was the empire's traces, especially in this relation with the "imagined communities" (Anderson, 1993), that tried to established the connection, giving a clear picture of that idea.

The various overseas territories were only confiscated by the Portuguese through the enactment of specific laws (e.g. the publication of the Colonial Act, in 1930, extinct in 1951), the regime propaganda, as well as the dissemination of images showing "Portugal from Minho to Timor" in its entire geographical extension. This way, as mentioned by Manuela Ribeiro Sanches from Gary Wilder, the imperial nation state was consecrated as a consistent whole, notwithstanding "the distinctive views, idiosyncrasies, contradictions and limits of the 'civilising missions', based on national disputes", which were also the basis of the modern nation state (Sanches, 2012, p. 195).

During the 1930s and 1940s, Lourenço Marques (currently, Maputo) is subject to several aesthetic interventions in its public space, aiming to "'monumentalise' and 'Portugalise' the city, trying to meet its newly acquired status of Colony capital" (Verheij, 2012 , p. 11). From these actions of the colonising country, two monuments should be highlighted: the World War I monument (by the sculptor Ruy Roque Gameiro, in collaboration with the architect Veloso Reis, de 1935), and the statue of Mouzinho de Albuquerque (Simões de Almeida, 1940) (Verheij, 2012, 2013, 2014). Around these monuments, celebrations take place, intended to give the monuments "the status of the Portuguese nation allegory", therefore playing an emphasised political role in the authoritative reformulation of the city's public space "as an 'imperial' space and in the putative hegemonisation of the representations of an imagined community as a 'Nation'”, allowing the 
approach of the use and political and ideological utility of the monument from the point of view of the organisation of the public space (Verheij, 2012, p. 11).

In Maputo, as soon as the Portuguese Revolution of 25 April took place, the colonial statues started to be demolished (except the World War I monument), and many of them were irremediably damaged. In a later stage, the Mozambican Government decided to change the dynamic initially adopted, showing the previous colonial statuary, in order to preserve the memory ${ }^{3}$, even though the trend goes in the direction of overthrowing the previous oppressor's traces, as it happens now in some places in the world. ${ }^{4}$. This is the case of the equestrian statue that honoured Mouzinho de Albuquerque, which was located in the heart of Maputo, in the square that was named after this Portuguese soldier during the colonial period, who was the Royal Commissioner of Mozambique between 1896 and 1898. This statue was transferred to the Maputo Fortress, where it can be seen, and that newlyweds use as a backdrop for their wedding photos, even though it personifies the former coloniser (Figure 1).

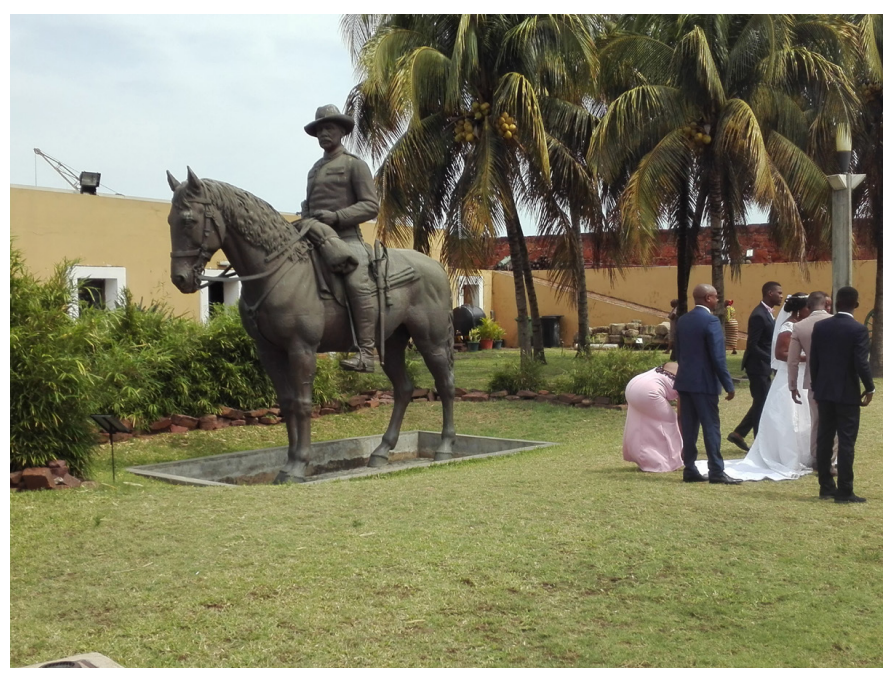

Figure 1: Statue of Mouzinho de Albuquerque, in Maputo Fortress, used as a scenario for wedding photos (photo taken by the author, in November 2018)

The statue of Mouzinho de Albuquerque is contextualised with a brief note. Riding a horse, in a scale beyond reality (4.90 metres high), Mouzinho is obvious as soon as we enter that space, which constitutes one of the main historical monuments in the city. This statue was transferred to this space after being, during the colonial period, in the same place where a bronze statue of Samora Machel now touches the sky (with 9.5 metres).

${ }^{3}$ Due to two research missions I did in November 2018, in Maputo, within the scope of CECS-Centro de Estudos de Comunicação e Sociedade and the project: "Memories, cultures and identities: how the past weights on the present-day intercultural relations in Mozambique and Portugal?", funded by the Aga Khan Development Network and the Portuguese Foundation for Science and Technology, I wrote an article for the post-colonial portal, Buala, titled "O que vale uma estátua? Memória e descolonização mental em Moçambique" [What is a statue worth? Memory and mental decolonisation in Mozambique]. Published in http://www.buala.org/pt/cidade/o-que-vale-uma-esta-tua-memo-ria-e-descolonizac-a-o-mental-em-moc-ambique.

${ }^{4}$ An example of this is the toppling of statues in Charlottesville, in Virginia, in 2017, intended to pay tribute to symbols of the Confederate States, showing the cleavage between its supporters, evoking the American Civil War, and its protesters, who considered them racist symbols that celebrate slavery. 
The square continues today its former monumental dynamic, also being marked by the Cathedral, the Municipality building and the wedding garden, officially known as Tunduro Botanical Garden, which underwent several advancements since it opened in 1855 .

The statue of Mouzinho de Albuquerque, which represents the man who took Ngungunhane as a trophy to Portugal and who is buried in the Maputo Fortress, after his mortal remains were transferred from Terceira Island (Azores), in 1985, was relocated and placed inside the enclosure, at the back, facing the only entrance and punctuating the entire space. The monument was removed from the place where it was initially built, during the first semester of 1975, following the independence of Mozambique.

The Maputo Fortress is, therefore, decolonised, following superior determinations. In addition, the public monuments of Maputo are protected by the Eduardo Mondlane University (the same applies to the Natural History Museum and National Art Museum), and it is possible to see several traces of the fight against the Portuguese coloniser in that spot. Something similar happens in Lisbon, regarding the building of Padrão dos Descobrimentos, built for the Portuguese World Exhibition of 1940, to serve the Estado Novo propaganda and that, nowadays, hosts exhibitions about racism and slavery. Nonetheless, as mentioned by Celso Azarias Inguane, "the building of social memory [is] (...) mainly dominated by state attempts of reproducing the national memory, establishing a national historical narrative and in continuity with colonial practices" (2007, p. ii).

The scenarios for wedding photos also extend to the Maputo train station, located in Praça dos Trabalhadores, through the use of locomotives, which were recovered and integrated in the musealisation of the space, inaugurated in June 2015. The train station is a building that dates back to 1910 and it is considered one of the most beautiful in the word.

The World War I monument is located in the centre of the same square (Figure 2).

This is a stone monument, by the sculptor Ruy Roque Gameiro, in collaboration with the architect Veloso Reis, which honours the African and European soldiers who died in the conflict - and this is the only monument built in Mozambique during the colonial period that favourably represents the Mozambican people (1935). This monument represents a woman with a snake at her feet, with references of the battles that took place in that country on its base (Mecula, Quivambo, Nevala and Quionga), where the warriors have weapons in their hands and the symbols of the Portuguese flag. In addition, the statue has in its right hand a fragment of a stone papyrus with the national coat of arms, symbolising the Portuguese Discoveries, although in its descriptive memory a more precise meaning is highlighted, since it refers to the retaking of Quionga, "which is, therefore, clearly integrated in a secular history of 'discoveries and conquests'" and, at the same time, it is "a palimpsest, a comment about what it was intended to be: a modern response to old stone monuments, durable marks of possession and domination" (Verheij, 2012, p. 21). 


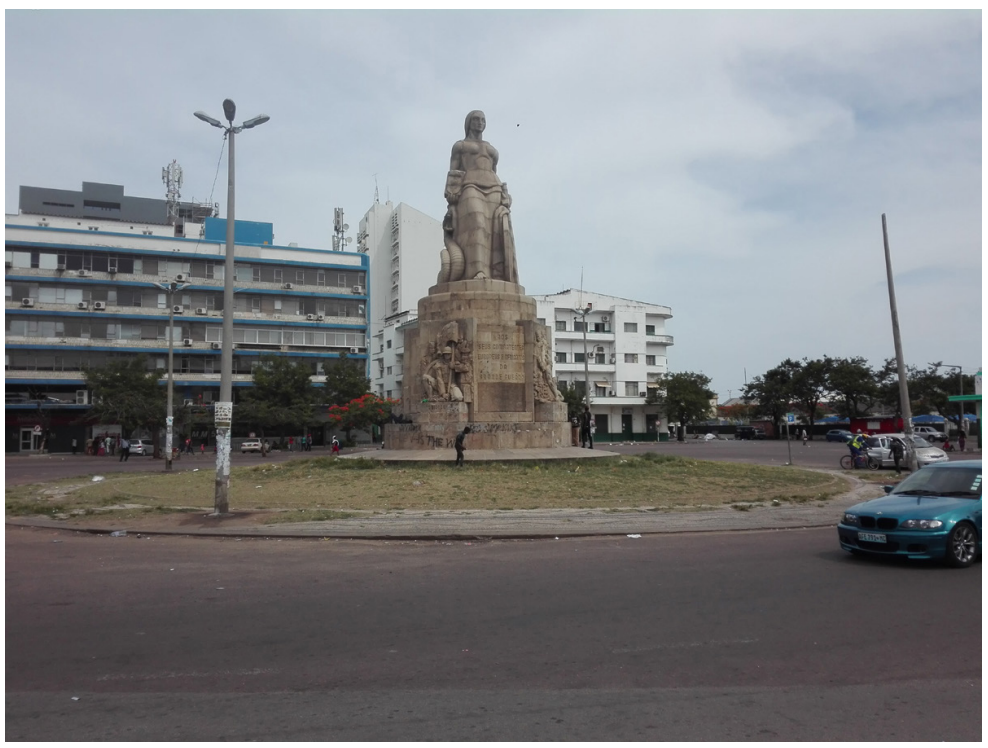

Figure 2: World War I monument, the only monument erected in Mozambique during the colonial period that favourably represents the Mozambican people, locally known as "Senhora da Cobra" [lady of snake] (November 2018)

Despite the colonial design of the statue, it is certain that it was recycled by Maputo citizens that preserved it not only because of its initial circumstance, which established the first great monument of dissemination of the imperial idea of the colony, "of a 'spirit policy', which aimed to 'nationalise' the colonial space” (Verheij, 2012, p. 25), but also due to a local legend, known as "Senhora da Cobra", which is not related to the reasons why the statue was built. This is easily proven by its descriptive memory. According to the legend, there was a snake on top of a tree in that region that attacked whoever passed there. On the path between the houses and the river, women and children were attacked and killed by the snake, until a woman decided to end this situation, by cooking a porridge and placing it in a pot balanced on her head. With the hot porridge, she walked towards the tree where the snake was hidden. The snake, while trying to attack the woman, fell into the pot and died. The woman returned to her community certain of her victory and everybody celebrated her courage. The statue, whose surrounding area is in a terrible state of conservation, is part of the imagination of Mozambican people, who value the female saviour more than those who died during the World War I, including Mozambicans.

Finally, a statue representing Salazar, which during the colonial period was erected in the centre of Maputo, occupying a prominent place, was placed in the National Library of Mozambique (which was previously the Municipal Library, opposite the Tivoli Hotel, in downtown Maputo), facing the wall (Figure 3). 


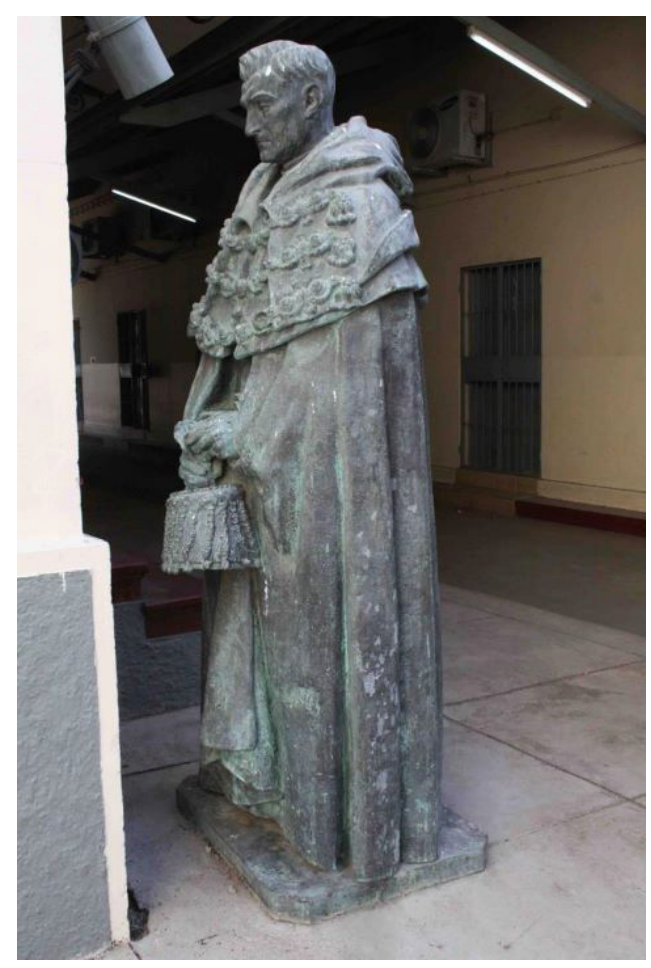

Figure 3: Statue of Salazar that during the colonial period was in the centre of
Maputo, and was later transferred to the building of the National Library of
Mozambique, facing the wall, as if the former dictator is being punished

Source: Paulo Pires Teixeira

It is as if the Mozambican people were punishing the former Portuguese dictator, an attitude of refined humour and that has been published in media and on social networks. Unlike the statue of Mouzinho de Albuquerque, this statue was not transferred to the Maputo Fortress, a place that, as we have seen, was devoted to showing the memory of Mozambique's colonial period. The large scale sculpture of Salazar, made of bronze, by Leopoldo de Almeida, shows the former dictator in a gown and looking straight ahead, but it faces, for several years now, the wall of the National Library. In this regard, Joaquim Chissano, former Head of State of Mozambique, explains that this did not happen by chance, because the point is to emphasise that history must not be forgotten ${ }^{6}$.

\section{FinAL REMARKS}

Roberto Vecchi understands Walter Benjamin's hesitation regarding the quote from the past, remembering that in the theses of this author about the concept of history, and drawing on Robespierre, he observed that "ancient Rome was a past loaded with today" (Vecchi, 2018b, s.p.). Note that the materialist historian's interest is reserved for the

\footnotetext{
${ }^{5}$ Retrieved from https://delagoabayworld.wordpress.com/category/historia/a-estatua-de-salazar-em-maputo/

${ }^{6}$ According to Joaquim Chissano, "Salazar existed, yes, he did. And he even did some good things that need to be remembered, but whether he is turned forward or facing the wall, for us, it is all the same, because we remember everything he did wrong, especially to our country, but also regarding the Portuguese people". Published in https://tvi24.iol.pt/internacional/ estatua/salazar-virado-para-a-parede-de-castigo-em-maputo
} 
past, "because of its quality of being completely passed, finished, of being definitively dead", which gives it the possibility of being quoted. And, it is in this hesitation that, according to Vecchi, the problem exists, related to the reuses of the past and its quote, "if the past is definitively finished, it will present less risks when compared to a past still in discussion", in which ideologies and reuses "may deeply change, or even reverse, the ways it is evoked" (Vecchi, 2018b, s.p.).

For the new state ideology, the representations could not be ambiguous, so the choice in terms of statuary, was always developed according to a one-dimensional dynamic, that "needed ways to establish the connection of these monuments with the collective memory and the present it proclaimed", as noted by Gerbert Verheij. This way, in a post-colonial period, "reintroducing the conflict that seems inherent to any interpretation of images in a modern era (...) seems, at last, necessary to understand the social role that the monument played in Lourenço Marques" (Verheij, 2012, p. 53). Even more so, it helps to understand the destination of the colonial legacy from which, through the independence of Mozambique (1975), the majority of traces was erased, despite the current trend that tends to preserve what remained following this attitude.

In the cases mentioned in this paper, regarding the new life of two colonial statues in Maputo, during the post-colonial period, and the permanence of the first monumental trace of Estado Novo, in the Mozambican capital, although with a genesis different from its initial objective by its inhabitants, the importance that the preservation of memory, even when it is associated with the former coloniser, in a country or a nation's life, can be observed. In the cases of the statue of Mouzinho de Albuquerque - relocated to the Maputo Fortress -, and the statue of Salazar - placed in the National Library facing the wall -, we can state that they contribute to the development of an interculturality, in a relation between the former colonised country, Mozambique, and the colonising country, Portugal. This sort of symbolic "airing" allows the Maputo citizens (and Mozambicans in general) to question their colonial past, assuming this part of their history, aiming to configure an identity, with less voids, which sail in a sea of memory and oblivion, and that mark the process of building the Mozambican nation (Khan et al., 2016).

In both cases, it is a sort of mental decolonisation (Thiong'o, 1986; Mbembe, 2017), which aims to question the way the colonial past currently weighs on the intercultural relations, in Mozambique, when the country looks at its past, subjugated by the Portuguese colonisation. In this sense, interculturality is promoted, in order to allow the overcoming of mistakes and the resolution of resentments. Marc Ferro (2009) mentions the existence of a reciprocity of resentments, observing that resentment is not only a matter of those who were identified as victims in the beginning. Research concludes that, simultaneously and alternately, resentment may affect, inhibit not only one of the parties, but both. The reaction after a revolution is obvious, but these types of paths are multiple and varied.

As advocated by Maria Paula Meneses, it is important to open historical narratives, "investing in interconnected histories, locally and regionally, challenging the legacies of colonial representations". This way, decolonisation should be assumed "as an act of 
awareness control, an act of liberation from oppression of knowledge as a monoculture". It is based on this context, that entering the $21^{\text {st }}$ century requires "a cartography network, dialogical, more complex and cautious of diversity that makes the epistemic and ontological alternatives visible, in addition to abyssal factures" (Meneses, 2018, 133).

The post-colonial period does not erase the colonial time, although it does recycle it in an aesthetic game full of indifference and ludic aspects: the colonial statue represents an absence/indifference, even if it playfully fills a photogenic space. Nonetheless, the Mozambican state contour in reproducing national memory, in a narrative that is in line with colonial practices. Even if, Mozambique is itself, a memory of colonisation.

So, we may ask, "what is a statue worth?". It is not enough that Mozambican politics invests in memory, by showing artefacts. This must be followed by an educational component, so the symbols are interpreted and the visible portion of the country's history being shown is understood, namely through statuary. Otherwise, taking photos with Mouzinho de Albuquerque as a backdrop, even if it is contextualised, will not have any relation with mental decolonisation, but with another thing, the freedom each person has. The same will occur regarding the statue of Salazar facing the wall of the National Library, which, if not contextualised, may be interpreted as simple resentment.

\section{Translation: Helena Antunes}

\section{FUNDING}

Research developed in the context of the project "Memories, cultures and identities: how the past weights on the presentday intercultural relations in Mozambique and Portugal?", supported by Aga Khan Development Network and PortuguesFoundation for Science and Technology. Translation of the English version supported by the same research project.

\section{REFERENCES}

Abadia, L., Cabecinhas, R., Macedo, I. \& Cunha, L. (2016). Interwoven migration narratives: identity and social representations in the Lusophone world. Identities - Global Studies in Culture and Power, 25(3), 339-357. https://doi.org/10.1080/1070289X.2016.1244062

Anderson, B. (1993). Imagined communities: reflections on the origin and spread of nationalism. London: Verso.

André, J. M. (2005). Diálogo intercultural, utopia e mestiçagens em tempos de globalização. Coimbra: Ariadne Editora.

Assmann, J. (2008). Communicative and cultural memory. In A. Erll \& A. Nunning (Eds.), Media and cultural memory (pp. 109-118). Berlin/New York: Walter de Gruyter.

Cabecinhas, R. (2007). Preto e branco: a naturalização da discriminação racial. Porto: Campo das Letras.

Cabecinhas, R. \& Cunha, L. (2008). Introdução. Da importância do diálogo ao desafio da interculturalidade. In R. Cabecinhas \& L. Cunha (Eds.), Comunicação intercultural. Perspectivas, dilemas e desafios (pp. 7-12). Porto: Campo das Letras. 
Cabecinhas, R. \& Feijó, J. (2010). Colective memories of Portuguese colonial action in Africa: representations of the colonial past among Mozambicans and Portuguese youths. International Journal of Conflict and Violence, 4.1, 38-44. Retrieved from http://hdl.handle.net/1822/11738

Canelas, L. (2014, 14 de dezembro). Entrevista a Fernando Bouza: "O Portugal dos Filipes é uma criação portuguesa". Público. Retrieved from https://pt.scribd.com/ document/252415558/O-Portugal-Dos-Filipes-e-Uma-Criacao-Portuguesa-PUBLICO

Coelho, J. P. B. (2004). As visitas do Dr. Valdez. Lisboa: Caminho.

Curto, D. R. (2018, 7 de maio). Atraso da História. Expresso. Retrieved from http://expresso.sapo.pt/ blogues/2018-05-07-Atraso-da-historia\#gs.xt=EdoU

Feijó, J. \& Cabecinhas. R. (2009). Representações da história de Moçambique por parte de estudantes universitários de Maputo. In Anuário Internacional de Comunicação Lusófona, 37-52. Vila nova de Famalicão: Húmus/Lusocom.

Ferreira, A. P. (2007). Specificity without exceptionalism: towards a critical Lusophone postcoloniality. In P. de Medeiros (Ed.), Lusophones literatures and postcolonialism (pp. 21-40). Utrecht: University of Utrecht, Portuguese Studies Center.

Ferro, M. (2009). O ressentimento na história. Lisboa: Teorema.

Halbwachs, M (1950/1990). A memória colectiva. São Paulo: Vértice.

Hespanha, A. M. (2019). Filhos da terra. Identidades mestiças nos confins da expansão portuguesa. Lisboa: Tinta da China.

Inguane, C. A. (2007). Negotiating social memory in postcolonial Mozambique: the case of heritage sites in Mandhlakazi district. Master of Arts in Social Anthropology, University of the Witwatersrand, Johannesburg. Australia.

Khan, S. (2008). Narrativas, rostos e manifestações do pós-colonialismo moçambicano nos romances de João Paulo Borges Coelho. Gragoatá, 13(24), 131-144. Retrieved from http://www.gragoata.uff.br/index. php/gragoata/article/view/252

Khan, S. (2007, 19 July). Entrevista com João Paulo Borges Coelho. Sines, Portugal.

Khan, S., Falconi, J. \& Krakowska, K. (2016). Moçambique, novas gerações em diálogo. Cerrados, 41, 314-329.

L'Estoile, B. (2008). The past as it leaves now: an anthropology of colonial legacies. Social Anthropology, 16(3), 267-279. https://doi.org/10.1111/j.1469-8676.2008.00050.x

Lacerda, T. (2016). Interculturalidade. In F. C. Domingues (Dir.), Dicionário da expansão portuguesa (14151600), Volume 2 (pp. 588-593). Lisboa: Círculo de Leitores

Marschall, S. (2009). Landscape of memory: commemorative monuments, memorials and public statuary in postapartheid South Africa, vol. 15. Boston: Brill.

Martins, L. P. (2012). Um império de papel. Lisboa: Edições 70.

Martins, M. L. (Ed.) (2015). Lusofonia e interculturalidade - promessa e travessia. Famalicão: Húmus.

Martins, M. L. (2018, 6 de abril). Descobertas/Descobrimentos e expansão. Viagem e travessia. Portugalidade e lusofonia. Correio do Minho. Retrieved from https://correiodominho.pt/cronicas/ descobertas-descobrimentos-e-expansao-viagem-e-travessia-portugalidade-e-lusofonia/9812 
Mbembe, A. (2017). Crítica da razão Negra. Lisboa: Antígona.

Meireles, L. (2016, 28 August). Entrevista a Sanjay Subrahmanyam "O império português era um império em rede". Expresso, pp. 50-58.

Meneses, M. P. (2018). Colonialismo como violência: a "missão civilizadora" de Portugal em Moçambique. Revista Crítica de Ciências Sociais [Special issue], 115-140.

Neves, J. (2016). Os sujeitos da História. In J. Neves (Ed.), Quem faz a História? Ensaios sobre o Portugal contemporâneo (pp. 9-16). Lisboa: Tinta da China.

Nora, P. (1989). Between memory and history: 'les lieux de mémoire'. Representations, 26, 7-24. https://doi. org/10.2307/2928520

Pereira, P. S. (2017, 25 August). A lusofonia, a ambivalência e as grelhas do ministro. Público. Retrieved from https://www.publico.pt/2017/08/25/mundo/ opiniao/a-lusofoniaa-ambivalencia-e-as-grelhas-do-ministro-1782621

Ribeiro, A. S. (2018). Pós-memória e compaixão - a razão das emoções. Jornal Memoirs, p. 15. Retrieved from https://www.ces.uc.pt/ficheiros2/files/MEMOIRS-encarte.pdf

Ribeiro, A. S. \& Ribeiro, M. C. (2018). A past that will not go away. The colonial war in Portuguese postmemory. Lusotopie, 17(2), 277-300. https://doi.org/10.1163/17683084-12341722

Ribeiro, M. C. (2004). Uma história de regressos, império, guerra colonial e pós-colonialismo. Porto: Edições Afrontamento.

Richards, T. (1993). The imperial archive. Knowledge and the fantasy of empire. London/ New York: Verso.

Ricœur, P. (2000). La memóire, l'histoire, l’oubli. Paris: Éditions du Seuil.

Sanches, M. R. (2012). A bem da Europa e das suas nações. In L. P. Martins, Um império de papel (pp. 195207). Lisboa: Edições 70.

Shepherd, N. \& Robins, S. (Eds.) (2008). New South African keywords. Johannesburg: Jacana/Athens: Ohio University Press.

Sousa, V. (2013). O conceito de diáspora em tempo de globalização. A relação entre império, lusofonia e 'portugalidade': um contrassenso? In M. Ledo, X. López \& M. Salgueiro (Eds.), Anuário Internacional de Comunicação Lusófona (17-29). Santiago de Compostela: Lusocom/Agacom.

Sousa, V. (2015). Da 'portugalidade' à lusofonia. Doctoral Thesis, Universidade do Minho, Braga, Portugal. Retrieved from http://repositorium.sdum.uminho.pt/handle/1822/38461

Sousa, V. (2017). Da 'portugalidade' à lusofonia. Vila Nova de Famalicão: Húmus.

Stoer, S. R. \& Cortesão, L. (1999). “Levantando a pedra" - da pedagogia inter/multicultural às políticas educativas numa época de transnacionalização. Porto: Afrontamento.

Subrahmanyam, S. (1995). O império asiático português 1500-1700. Uma história política e económica. Lisboa: Difel.

Thiong'o, N. (1986). Decolonising the mind: the politics of language in African literature. Portsmouth: Heinemann Educational.

Todorov, T. (2002). Memória do mal, tentação do bem. Uma análise do século XX. Porto: Edições Asa. 
Torgal, L. R. (2009). Estados novos, Estado Novo, Vol. 1. Coimbra: Imprensa da Universidade de Coimbra.

Vecchi, R. (2018a). Depois das testemunhas: sobrevivências. Jornal Memoirs, p. 18. Retrieved from https:// www.ces.uc.pt/ficheiros2/files/MEMOIRS-encarte.pdf

Vecchi, R. (2018b, 19 December). Os (re)usos do passado. [Blog post]. Retrieved from http://www.buala.org/ pt/a-ler/os-reusos-do-passado

Verheij, G. (2012). Monumentalidade e espaço público em Lourenço Marques nas Décadas de 1930 e 1940. On the waterfront, 20, 11-54.

Verheij, G. (2013). Art and politics in the former "Portuguese Colonial Empire". The monument to Mouzinho de Albuquerque in Lourenço Marques. RIHA Journal 0065. Retrieved from http://www.riha-journal.org/ articles/2013/2013-jan-mar/verheijmouzinho-monument-marques

Verheij, G. (2014). Monumentos coloniais em tempos pós-coloniais. A estatuária de Lourenço Marques. In B. F. Torras (Ed.), Actas do IV Congresso de História da Arte Portuguesa em homenagem a José Augusto França (pp. 36-45). Lisboa: APHA.

\section{BIOGRAPHICAL NOTE}

Vítor de Sousa has a PhD in Communication Sciences (Intercultural Communication), by the University of Minho, with the thesis: Da 'portugalidade' à lusofonia [From 'Portugality' to Lusophony], he has a Master's Degree (specialised in Media Education) and a Bachelor's Degree (specialised in Information and Journalism) in the same area. Among his research areas are questions surrounding identity, Cultural Studies, Media Education and Journalism theories. He is a researcher at CECS (Communication and Society Research Centre), where he integrates the Group of Cultural Studies, is a member of the project: "CulturesPast\&Present - Memories, cultures and identities: how the past weights on the present-day intercultural relations in Mozambique and Portugal?" (FCT/ Aga Khan) and Museu Virtual da Lusofonia. He is a member of Sopcom, ECREA and Associação dos Amigos da Biblioteca Municipal de Penafiel. He won the Mário Quartim Graça 2016 Scientific Award, which distinguishes the best doctoral thesis in the last three years in the area of Social Sciences and Humanities, in Portugal and in Latin America. He was a journalist (1986-1997) and a press officer (1997-2005).

ORCID: https://orcid.org/oooo-0002-6051-0980

Email: vitordesousa@gmail.com

Address: CECS-Centro de Estudos de Comunicação e Sociedade, ICS-Instituto de Ciências Sociais, Universidade do Minho, Campus de Gualtar, 4710-057 Braga - PORTUGAL

$*$ Submitted: 04/02/2019
$*$ Accepted: 07/03/2019 